\title{
Espécies novas de Anthrenoides Ducke (Hymenoptera, Apidae, Andreninae) da Argentina ${ }^{1}$
}

\author{
Danúncia Urban ${ }^{2}$
}

${ }^{1}$ Contribuição no 1767 do Departamento de Zoologia, Universidade Federal do Paraná.

${ }^{2}$ Departamento de Zoologia, Universidade Federal do Paraná. Caixa Postal 19020, 81531-980 Curitiba-PR, Brasil. Bolsista do CNPq. urban@ufpr.br

\begin{abstract}
New species of Anthrenoides Ducke (Hymenoptera, Apidae, Andreninae) from Argentina. Anthrenoides calderensis sp. nov., A. cordobensis sp. nov., A. gibberosus sp. nov., A. neffi sp. nov., A. punctatus sp. nov., A. saltensis sp. nov., A. sanpedroi sp. nov., A. tucumanus sp. nov. and A. villaguayensis sp. nov. are described and illustrated. A key to identify the species is presented.

KEYWORDS. Apoidea; new species; Protandrenini; Neotropical; taxonomy.

RESUMO. Espécies novas de Anthrenoides Ducke (Hymenoptera, Apidae, Andreninae) da Argentina. São descritas e ilustradas as seguintes espécies: A calderensis sp. nov., A. cordobensis sp. nov., A. gibberosus sp. nov., A. neffi sp. nov., A. punctatus sp. nov., A. saltensis $\mathbf{s p .}$ nov., A. sanpedroi $\mathbf{s p .}$ nov., A. tucumanus sp. nov. e A. villaguayensis sp. nov. É apresentada uma chave para a sua identificação.
\end{abstract}

PALAVRAS-CHAVE. Apoidea; espécies novas; Protandrenini; Neotropical; taxonomia.

Espécies de Anthrenoides Ducke, 1907, do sul, sudeste e nordeste brasileiros foram estudadas por Urban (2005a, b, 2007). Para dar continuidade ao conhecimento do gênero são descritas algumas espécies novas da Argentina. Conforme o catálogo das espécies de abelhas da região Neotropical (Moure et al., 2007), a única espécie de Anthrenoides previamente conhecida da Argentina é A. meridionalis (Schrottky, 1906), de Catamarca, Mendoza e Misiones. É possível que alguns desses registros da Argentina sejam referentes a outras espécies. As descrições seguem a terminologia comumente utilizada nas descrições das abelhas e as medidas são dadas em milímetros. A asa anterior foi medida a partir do esclerito costal e o comprimento da cabeça corresponde à distância do vértice ao ápice do clípeo. Nos comentários são feitas algumas comparações com espécies conhecidas do sul e do sudeste do Brasil. O material-tipo está depositado na Coleção Entomológica Pe. J. S. Moure, Universidade Federal do Paraná, Curitiba (DZUP) e na coleção do Museo Argentino de Ciencias Naturales, Buenos Aires (MACN).

\section{Anthrenoides calderensis sp. nov.}

(Fig. 1)

Diagnose. Macho com as máculas cefálicas esbranquiçadas e o labro preto; fóveas faciais ovóides; mesoscuto e escutelo micro-reticulados; tergo basal com micro-reticulação superficial e área polida somente junto à faixa marginal; gálea quase tão longa como o olho. Fêmea com as fóveas faciais largas e longas, elipsóides, carena frontal curta e fina; supraclipeal micro-reticulada. Palpômero labial basal pouco maior que a soma dos demais, estes um pouco maiores que o diâmetro do ocelo mediano.
Holótipo macho. Comprimento aproximado 6,17; comprimento da asa 5,53; largura da cabeça 1,70; comprimento da cabeça 1,67; comprimento do olho 1,06. Tegumento predominante preto, o clípeo esbranquiçado com a margem e duas pequenas nódoas pretas semi-circulares próximas das fóveas tentoriais, com orla preta muito estreita junto à sutura epistomal; as máculas paroculares esbranquiçadas curtas e quase retangulares, com o contorno dorsal irregular; antenas com o escapo e o pedicelo pretos, os demais artículos enegrecidos; tégulas enegrecidas; asas tingidas fracamente de enegrecido com as veias castanho-enegrecidas menos as veias C+ Sc e R, prestigma e pterostigma pretos; os tergos com faixa distal castanho-enegrecida.

Placa labral um pouco mais estreita na ponta, com os cantos arredondados e carenas laterais até o meio; clípeo sem carena mediana, com micro-reticulação superficial e pontos grandes muito rasos e esparsos; supraclipeal micro-reticulada com pontos rasos mais esparsos que os clipeais; fronte microreticulada e brilhante com pontos pouco densos e carena fina e curta ultrapassando a área interalveolar; fóveas faciais ovóides, curtas e largas, medindo cerca de $1 / 5$ do comprimento do olho $(0,21: 1,06)$; genas, de perfil, fracamente angulosas e estreitando muito em direção às mandíbulas. Mesoscuto e escutelo micro-reticulados e brilhantes com pontos distribuídos regularmente, um pouco maiores e mais esparsos no escutelo; área basal do propódeo pouco mais curta que o metanoto, micro-reticulada, com uma rúgula mediana e o contorno posterior pouco marcado; mesepisternos microreticulados com pontos esparsos e pouco perceptíveis. Tergo basal com áreas subapicais polidas nos lados junto à faixa marginal, com micro-reticulação muito fraca e pontos diminutos 
no disco e na base; os três tergos seguintes polidos no disco e com pontos pouco maiores e mais densos que os do tergo basal; a faixa marginal dos tergos brilhante, com microreticulação muito superficial. Sexto esterno com o recorte em "U" sem alargamento basal e com as margens divergindo um pouco para a ponta, com carena basal em arco, contínua com os bordos laterais do recorte, limitando uma faixa apical muito estreita; projeção mediana do $8^{\circ}$ esterno arredondada e tão larga como o diâmetro do ocelo mediano.

Pilosidade branca, com pêlos curtos e longos no colar pronotal; esparsa no mesoscuto, com pêlos longos intercalados entre a pilosidade curta; esparsa e fina nos tergos.

Fêmea. Comprimento aproximado 6,89; comprimento da asa 5,91; largura da cabeça 2,09; comprimento da cabeça 1,91; comprimento do olho 1,34. Tegumento preto incluindo as antenas e pernas, menos o esporão mesotibial enegrecido e o tarsômero distal acastanhado; as tégulas translúcidas e um pouco enegrecidas e as asas tingidas de castanho com as veias enegrecidas; os tergos e esternos com faixa marginal enegrecida.

Placa labral trapezoidal com pequeno chanfro na ponta, os lados carenados ao longo do recorte côncavo raso, com uma rúgula mediana longa e rúgulas basais muito curtas; clípeo micro-reticulado e brilhante quase até a ponta, com pontos grandes um pouco mais rasos dorsalmente e carena mediana pouco marcada; supraclipeal micro-reticulada com pontos rasos menores que os clipeais, muito esparsos no disco; carena frontal fina e mais curta que a área supraclipeal; fóveas faciais largas e longas, distintamente contornadas, mais largas que $o$ ocelo mediano e maiores que $1 / 3$ do comprimento do olho $(0,51: 1,34)$. Mesoscuto, escutelo, mesepisternos e asas como no macho; área basal do propódeo quase lisa, com poucas rúgulas basais curtas e irregulares e o contorno bem marcado; esporão mesotibial com seis dentes fortes e alguns dentículos basais. Tergos como no macho.

Pilosidade como no macho. Nas pernas predominam os pêlos brancos, menos na face externa das tíbias e basitarsos com pêlos castanho-enegrecidos, as tíbias posteriores com cerdas enegrecidas porém a ponta esbranquiçada; mesepisternos com cerdas finas com a ponta dobrada em forma de gancho.

Holótipo macho. ARGENTINA, Salta. "AR, Salta, $11 \mathrm{~km} \mathrm{NE} \mathrm{/} \mathrm{La}$ Caldera 1490m / 18.I.2008 K. Ramos" (MACN). Parátipos com os mesmos dados do holótipo, um macho e uma fêmea (DZUP).

Comentários. Chama a atenção no parátipo a parte ventral das genas não estreitada, ao contrário, ventralmente larga, com angulosidade e um tubérculo pequeno. O macho, na chave de Urban (2005a) sai com A. pinhalensis Urban, 2005, que difere principalmente pelo palpômero labial basal muito longo e pelo sexto esterno com alargamento basal no recorte mediano em "U"; na chave de Urban (2007) sai com A. lavrensis Urban, 2007, que tem a metade apical do clípeo esbranquiçada e a basal preta, o pterostigma amarelo-acastanhado e alargamento na base do recorte do sexto esterno. A fêmea sai, na chave de
Urban (2005) com A ornatus Urban, 2005, que tem as asas amareladas com as veias e o pterostigma de um amarelo-âmbar muito pálido.

Etimologia. Nome relativo à localidade-tipo.

\section{Anthrenoides cordobensis sp. nov.}

(Figs. 2, 7, 16)

Diagnose. Fêmea com o clípeo, área supraclipeal, mesoscuto e escutelo polidos e esparsamente pontuados; face ventral dos mesepisternos com cerdas dobradas em forma de gancho. Macho com o labro enegrecido, as máculas cefálicas amarelas, clípeo, supraclipeal e paroculares inferiores polidos e com pontos finos esparsos; mesoscuto e escutelo polidos com áreas micro-reticuladas em volta.

Holótipo fêmea. Comprimento aproximado 7,56; comprimento da asa 4,44; largura da cabeça 1,82; comprimento da cabeça 1,35; comprimento do olho 1,01. Tegumento preto na cabeça e mesossoma; antenas com o escapo em parte enegrecido e em parte castanho, face dorsal do flagelo castanha e a ventral castanho-clara a partir da ponta do terceiro flagelômero. Tégulas translúcidas amarelo-âmbar, asas com as veias e o pterostigma amarelo-âmbar, a membrana também tingida desta cor; esporão mesotibial translúcido amarelado. Tergos com larga faixa marginal translúcida amarelada, os basais castanhos e, do terceiro ao quinto castanhoenegrecidos; os três esternos basais castanho-claros e os demais enegrecidos com a margem esbranquiçada estreita.

Placa labral com rúgulas irregulares muito esparsas, arredondada nos cantos e com as carenas laterais quase até a base; clípeo, área supraclipeal e paroculares inferiores polidos com pontos esparsos maiores que os pontos mesoscutais; o clípeo sem carena mediana, com os espaços entre os pontos maiores que o diâmetro do ocelo mediano; supraclipeal um pouco protuberante em direção ao sulco frontal, com grande área discal sem pontos e pontuada irregularmente junto às suturas subantenais; fronte sem carena, elevada medianamente e com um sulco pouco mais longo que a área supraclipeal, terminando ventralmente em um ponto pouco maior que os adjacentes; fóveas faciais estreitas, com alargamento mediano e o contorno dorsal pouco definido, mais longas que $1 / 3$ do comprimento do olho $(0,36: 1,01)$. Mesoscuto e escutelo polidos com micro-reticulação fraquíssima no contorno, pontos de tamanho variável e áreas grandes sem pontuação no disco; esporão mesotibial quase tão longo como o basitarso, com 4 dentes grossos e dentículos muito curtos e finos para a base; depressão basal do propódeo tão longa como o metanoto, micro-reticulada e com algumas rúgulas basais divergentes para os lados, o contorno posterior marcado no meio; mesepisternos micro-reticulados; tergos micro-reticulados brilhantes com a faixa marginal micro-reticulada, o basal com pouquíssimos pontos rasos, segundo tergo com pontos mais densos, do tamanho dos retículos e até a faixa marginal, primeiro ao quarto com áreas látero-dorsais polidas junto à faixa marginal.

Pilosidade branca esparsa, passando a denso-plumosa e 

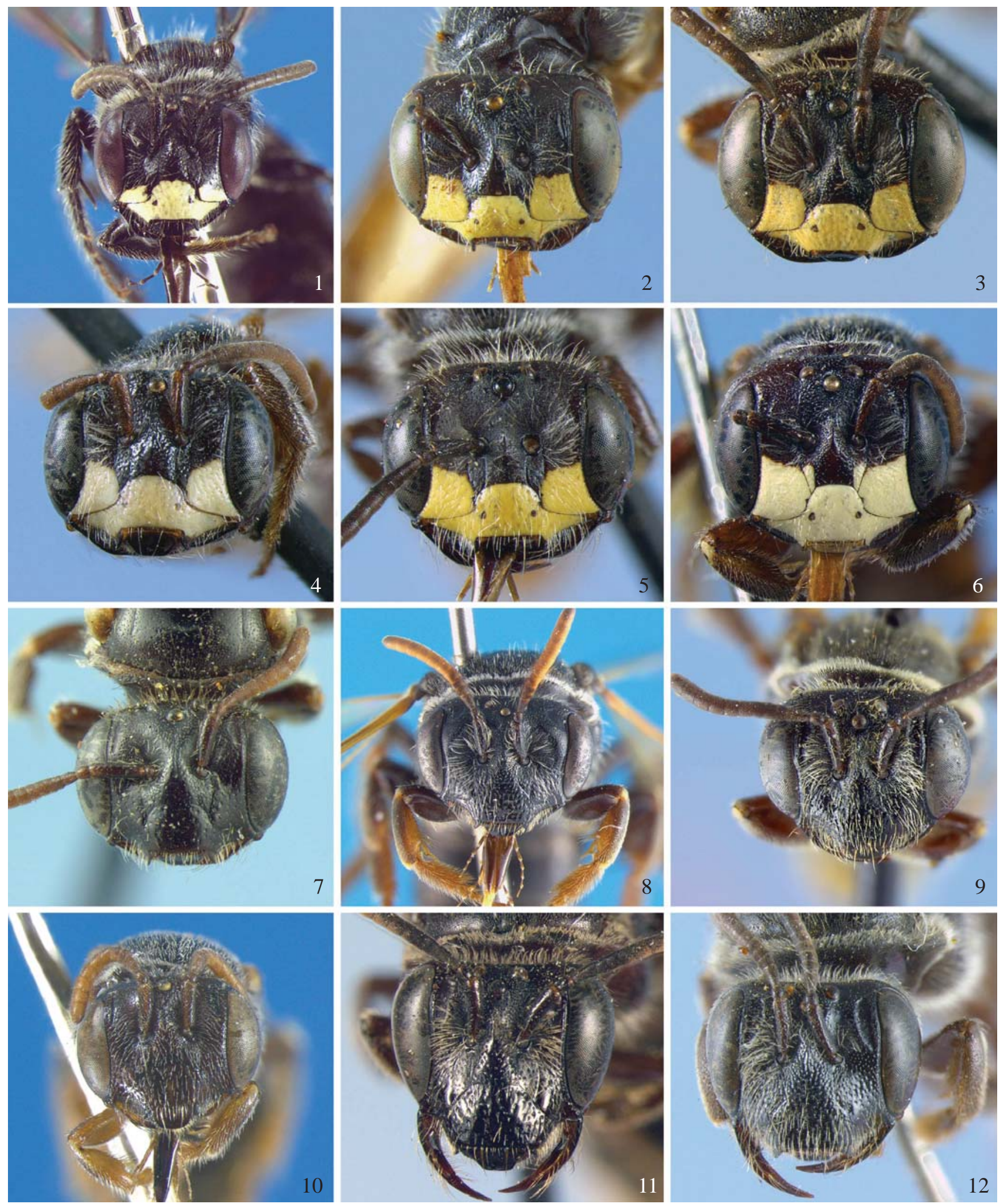

Figs. 1-12. Vista frontal da cabeça, machos (1-6) e fêmeas (7-12). 1, Anthrenoides calderensis sp. nov. , holótipo; 2, A. cordobensis sp. nov., parátipo; 3, A. neffi sp. nov., holótipo; 4, A. sanpedroi sp. nov., holótipo; 5, A. tucumanus sp. nov., holótipo; 6, A. villaguayensis sp. nov., holótipo; 7, A. cordobensis sp. nov., holótipo; 8, A. gibberosus sp. nov., holótipo; 9, A. neffi sp. nov., parátipo; 10, A. punctatus sp. nov., holótipo; 11, A. saltensis sp. nov., holótipo; 12, A. sanpedroi sp. nov., parátipo. 
curta no colar pronotal; um pouco amarelada em parte das pernas, porém branca na face externa das tíbias posteriores; face ventral dos mesepisternos com cerdas finas e curtas, eretas, dobradas em gancho na ponta; muito curta e fina nos tergos basais, longa no quinto e sexto.

Macho. Comprimento aproximado 5,97; comprimento da asa 4,41; largura da cabeça 2,04; comprimento da cabeça 1,41; comprimento do olho 1,15. Tegumento preto menos o clípeo e as paroculares inferiores amarelos; o clípeo com duas nódoas arredondadas próximas das fóveas tentoriais e o bordo pretos; máculas paroculares quase quadradas, com o contorno dorsal sinuoso; antenas com o escapo e o pedicelo pretos; tégulas castanhas; asas tingidas de castanho claro, $\mathrm{R}$ enegrecida; pernas castanhas, tíbias e tarsos medianos e posteriores de cor âmbar, a tíbia mediana com nódoa amarelada na base e a posterior com a placa basitibial amarelada no disco. Tergos como na fêmea.

Placa labral com os cantos arredondados, a ponta mais estreita que a base; clípeo, supraclipeal e paroculares inferiores como na fêmea; fronte sem carena mediana, com um sulco muito fino quase até o ocelo mediano; fóveas faciais estreitas e curtas, medindo menos de $1 / 4$ do comprimento do olho $(0,24$ : $1,15)$; genas mais largas que os olhos, em vista de perfil, com angulosidade ventral obtusa; mesoscuto, escutelo e mesepisternos como na fêmea; área basal do propódeo tão longa como o metanoto, micro-reticulada e com rúgulas fracas irregulares; tergos micro-reticulados brilhantes com larga faixa marginal micro-reticulada, os quatro basais com pouquíssimos pontos finos, quinto e sexto mais brilhantes; sexto esterno com o recorte em "U" sem alargamento basal, tão longo como largo, com as carenas basais formando um arco incompleto, deixando uma área mediana lisa; ponta do oitavo esterno tão larga como o dobro do diâmetro do ocelo mediano e arredondada nos cantos.

Pilosidade branca e esparsa.

Holótipo fêmea. ARGENTINA, Córdoba. "88554"; "RA: Cordoba / Jesus Maria / 3-XII-73 J. L. Neff”; " C “ (DZUP). Parátipos com os mesmos dados do holótipo, "88553", "88555", "88557", três fêmeas: "San Isidro, Buenos / Aires, Argentina / XII - 50 L. Plaumann", um macho (todos no DZUP).

Comentário. No holótipo a pilosidade do pronoto está um pouco danificada, porém um dos parátipos, fêmea, tem pilosidade curta, densa e com aspecto aveludado no colar pronotal. O parátipo macho, além da pilosidade bastante danificada, tem somente os dois artículos basais da antena direita; a perna mediana e a posterior e as asas lado direito. $\mathrm{Na}$ chave proposta por Urban (2005a) a fêmea sai com A. rodrigoi Urban, 2005, que difere pelas fóveas faciais bem delimitadas, o tergo basal denso-pontuado e a base do propódeo mais curta que o metanoto e com rúgulas paralelas. $\mathrm{O}$ macho sai $\operatorname{com} A$. meridionalis (Schrottky, 1906), que difere pelo tergo basal polido e com pontuação na área discal, pela faixa marginal brilhante dos tergos e os mesepisternos com áreas laterais polidas.

Etimologia. Nome relativo à localidade-tipo.

\section{Anthrenoides gibberosus sp. nov.} (Fig. 8)

Diagnose. Fêmea com as fóveas faciais quase circulares, no topo da cabeça, limitadas ventralmente por projeções do tegumento em forma de meia-lua e duas projeções gibosas abaixo dos ocelos laterais; clípeo polido e com carena mediana; antenas com os flagelômeros medianos e distais amareloâmbar.

Holótipo fêmea. Comprimento aproximado 8,30; comprimento da asa 5,63; largura da cabeça 2,54; comprimento da cabeça 1.86; comprimento do olho 1,23. Tegumento predominante preto. As antenas com o escapo e o pedicelo enegrecidos, os flagelômeros amarelo-âmbar menos a face dorsal castanha nos quatro basais. Tégulas translúcidas castanhas; as asas tingidas fracamente de amarelo-âmbar com as veias e o pterostigma também desta cor, menos a $R$, um pouco acastanhada. Tíbias anteriores com a face anterior amarelo-âmbar e pequena nódoa basal amarela; as tíbias medianas com pequena área amarelo-âmbar nas adjacências do esporão e nódoa basal amarela; as posteriores com a tíbia quase inteiramente amarelo-âmbar, placa basitibial com a metade basal e o contorno castanhos; esporão mesotibial castanho com a ponta esbranquiçada; os tarsos amarelo-âmbar. Tergos e esternos com faixa marginal castanha, mais estreita e com o bordo translúcido nos esternos.

Placa labral larga, com o contorno arredondado e a ponta quase reta, sem rúgulas e com as carenas laterais quase até a base; clípeo polido, com carena mediana baixa e pontos grandes conspícuos; supraclipeal polida e pontuada, os pontos pouco menores que os clipeais porém mais densos. Fronte com um sulco mediano fino, mais longo que a metade do comprimento do escapo, a partir da área interalveolar, o sulco orlado por carenas finas irregulares que divergem dorsalmente e com duas projeções gibosas ventralmente aos ocelos laterais; paroculares com protuberâncias dorsais em forma de em meialua, ultrapassando a metade do olho, muito largas dorsalmente e estreitadas na parte ventral. Fóveas faciais quase circulares, em vista dorsal alcançando o nível inferior dos ocelos laterais, medindo menos de $1 / 3$ do comprimento do olho $(0,37: 1,23)$. Mesoscuto brilhante, com micro-reticulação esparsa e muito superficial, os pontos distribuídos irregularmente, variando no tamanho, esparsos ou agrupados; escutelo polido com pontos pouco maiores que os mesoscutais e pontos muito pequenos; área basal do propódeo mais curta que o metanoto com rúgulas muito finas e o contorno posterior pouco marcado; mesepisternos micro-reticulados e brilhantes com pontos tão grandes com os mesoscutais; esporão mesotibial com o dente apical quase tão longo como o diâmetro ocelar e dois dentes subapicais pouco maiores que os demais. Tergo basal micro-reticulado e brilhante, com pontos finos não densos, o segundo e terceiro tergos com pontuação mais densa; faixa marginal dos tergos micro-reticulada e brilhante.

Pilosidade branca, densa e curta, com aspecto aveludado no colar pronotal, um pouco mais alongada nos lobos 

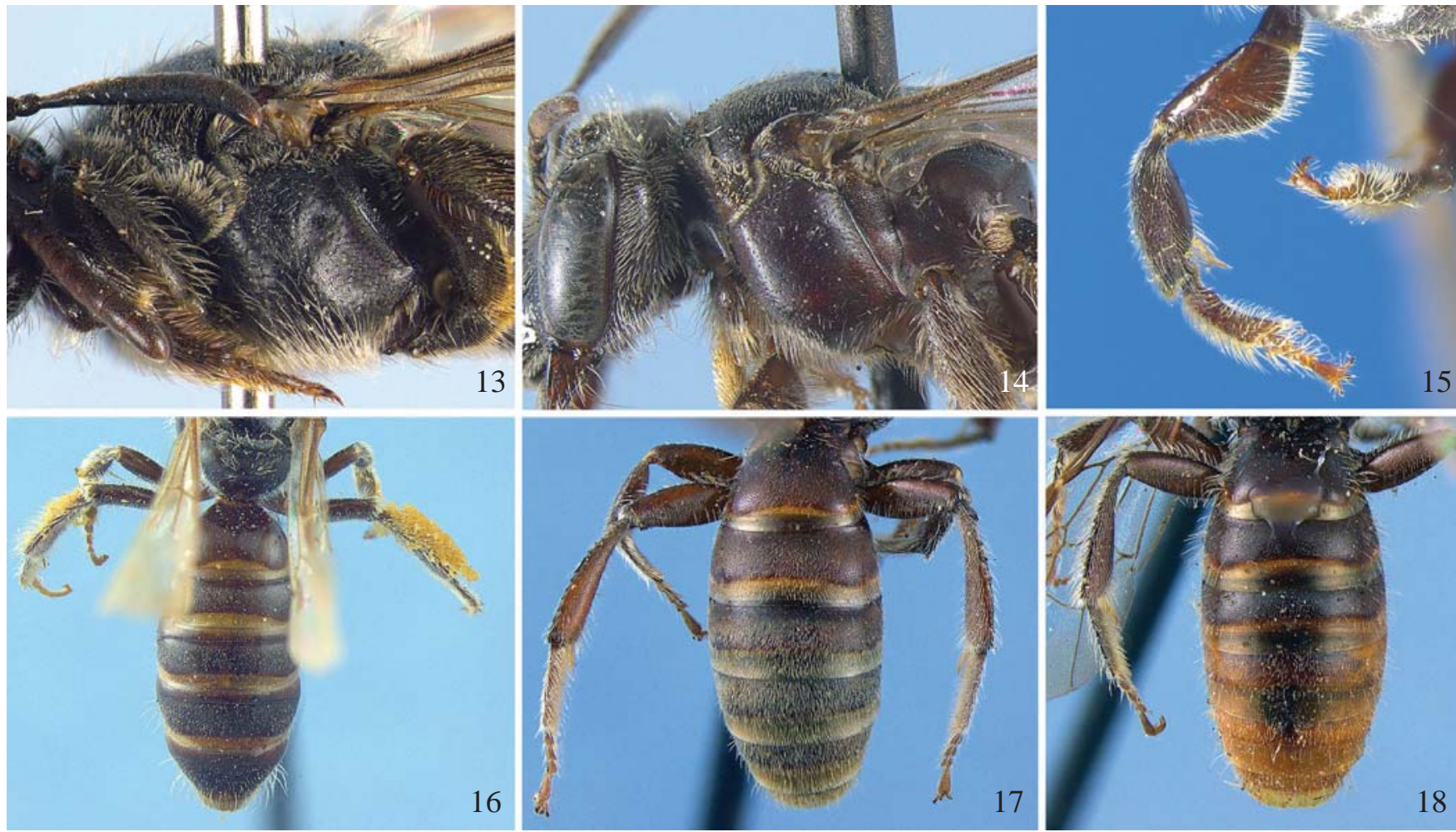

Figs. 13-18. Mesossoma da fêmea em vista de perfil (13-14), detalhe das pernas anteriores da fêmea (15) e tergos do holótipo (16-18). 13. Anthrenoides larocai; 14, A. saltensis sp.nov., holótipo; 15, A. neffi sp. nov., parátipo; 16, A. cordobensis, sp. nov.; 17, A. neffi sp. nov.; 18, A. tucumanus sp. nov.

pronotais; cerdas ventrais dos mesepisternos brancas, eretas, com a ponta um pouco arqueada ou dobrada; branca na face dorsal das tíbias e tarsos, e amarelada na face ventral dos basitarsos.

Holótipo fêmea. ARGENTINA, Córdoba. "Argentinien, Córdoba, El Durazno / Gymnocalycium multiflorum / 29.11.1998 / leg B. Schlumpberger" (DZUP). Parátipo com os mesmos dados do holótipo, 1 fêmea (DZUP).

Comentários. Entre as espécies de Anthrenoides conhecidas da Argentina, é a única com protuberâncias cefálicas.

Etimologia. Nome relativo às projeções dorsais da cabeça. Macho desconhecido.

\section{Anthrenoides neffi sp. nov.}

(Figs. 3, 9, 15, 17)

Diagnose. Tanto o macho como a fêmea com os tergos denso-pontuados, inclusive o basal, revestidos com pêlos curtos amarelo-dourados até a margem. Nas fêmeas, chamam a atenção os basitarsos anteriores, arqueados dorsoventralmente, ornados na ponta com cerdas longas dobradas em forma de gancho.

Holótipo macho. Comprimento aproximado 7,15; comprimento da asa 5,50; largura da cabeça 2,26; comprimento da cabeça 1,64; comprimento do olho 1,21. Tegumento predominante preto, exceto o clípeo e as paroculares inferiores amarelos, o clípeo com a margem e duas nódoas arredondadas enegrecidas próximas das fóveas tentoriais, a mácula das paroculares até a metade da sutura subantenal externa, mais longa junto à órbita; antenas com a face ventral castanha a partir do terceiro flagelômero; tégulas translúcidas castanhoamareladas; asas tingidas de amarelo-méleo; pernas castanhas, as tíbias anteriores e medianas com mácula basal amarelopálida; esporão mesotibial esbranquiçado; tergos e esternos castanho-enegrecidos com larga margem translúcida amareloesbranquiçada.

Placa labral curta, um pouco mais larga na base e com uma pequena emarginação na ponta, as carenas laterais até a base; clípeo polido com pontos grandes esparsos, sem carena mediana; supraclipeal no mesmo plano do clípeo e com elevação fraca em direção à área interalveolar, brilhante e com micro-reticulação fraca, os pontos mais densos que no clípeo, porém com uma área sem pontos ao longo do meio e junto ao clípeo; fronte denso-pontuada, sem carena mediana; fóveas faciais estreitas, alargando dorsalmente e um pouco mais longas que $1 / 4$ do comprimento do olho $(0,34: 1,21)$; genas com angulosidade ventral obtusa; mesoscuto polido e densopontuado, os intervalos igualando o tamanho dos pontos; escutelo polido com os espaços entre os pontos variando entre 2 e 3 diâmetros de ponto; área basal do propódeo um pouco mais longa que o metanoto, com rúgulas irregulares e o 
contorno posterior marcado medianamente; mesepisternos polidos no disco das áreas laterais, com micro-reticulação fraca em volta; tergos polidos e denso-pontuados, incluindo o basal, com a margem lineolada irregularmente e um pouco fosca; sexto esterno com o recorte em "U" um pouco mais largo que longo, com pequeno alargamento na base e a carena basal quase reta, contínua com os bordos laterais do recorte; ponta do oitavo esterno com os cantos arredondados, medindo o dobro do diâmetro do ocelo mediano.

Pilosidade branca na cabeça e mesossoma, muito curta e densa na face posterior do colar pronotal e nos lobos; nos tergos amarelo-dourada, decumbente, curta e fina até o bordo.

Fêmea. Comprimento aproximado 8,0; comprimento da asa 6,57; largura da cabeça 2,42; comprimento da cabeça 1,86; comprimento do olho 1,33. Tegumento preto sem desenhos amarelos na cabeça; as pernas, o mesossoma e o metassoma como no macho. Esporão mesotibial amarelo-âmbar.

Placa labral quase retangular, sem rúgulas, um pouco mais larga que longa, com os cantos arredondados e as carenas laterais quase até a base; clípeo polido, com pontos grandes esparsos, sem carena mediana; supraclipeal polida no disco e com micro-reticulação brilhante em volta, um pouco elevada junto à área interalveolar e com pontuação densa, os pontos menores que os do clípeo; fronte pontuada, sem carena mediana; fóveas faciais um pouco alargadas subapicalmente, medindo cerca de $1 / 3$ do comprimento do olho $(0,43: 1,33)$; mesoscuto e escutelo como no macho, os mesepisternos com áreas micro-reticuladas esparsas; área basal do propódeo mais curta que o metanoto e com rugosidades fracas, o contorno posterior marcado só no meio; basitarsos anteriores arqueados dorso-ventralmente; esporão mesotibial com 5 dentes muito delgados; tergos como no macho, com micro-reticulação fraquíssima nos lados do basal.

Pilosidade branca na cabeça e mesossoma, muito curta e densa na face posterior do colar e nos lobos pronotais; face externa das tíbias posteriores com cerdas bicoloridas, castanhas na base e esbranquiçadas no restante; nos tergos amarelo-dourada e densa até o bordo, como no macho. Basitarsos anteriores ornados distalmente com cerdas finas e longas com o ápice em forma de gancho, face ventral dos tarsômeros intermediários com algumas cerdas de ápice dobrado em gancho; mesepisternos com cerdas finas, curtas e decumbentes, menores que o diâmetro do ocelo mediano, não dobradas na ponta.

Holótipo macho. ARGENTINA, Catamarca. "73982", "ARGENT; Pr. [Província] Catamarca, Buena Vista - Aconquija / Int. Biol. Program / collector J. L. Neff / \# refers to host \& date / 5.XI.1972", "A" (DZUP). Parátipos com os mesmos dados do holótipo, "73984", um macho; "75239", "73914" e "73979", três fêmeas (todos no DZUP).

Comentário. Pela chave de Urban (2005a) o macho sai com A. araucariae Urban, 2005, que difere pelos tergos polidos e brilhantes com pontos finos esparsos e a margem brilhante e sem micro-reticulação; a fêmea sai com A. corrugatus Urban, 2005 , que se distingue pelos tergos polidos com pontos finos e pilosidade pouco conspícua, os pêlos muito esparsos no tergo basal e as cerdas da área ventral dos mesepisternos, mais longas que uma vez e meia o diâmetro do ocelo mediano.

Etimologia. Dedicada ao coletor do espécime, J. L. Neff.

\section{Anthrenoides punctatus sp. nov.}

(Fig. 10)

Diagnose. Fêmea com o clípeo e a supraclipeal polidos e pontuados, mesoscuto e escutelo polidos; placa labral sem rúgulas; fronte com sulco mediano orlado com carenas pontuadas; esporão mesotibial com 3 espinhos muito curtos na metade apical.

Holótipo fêmea. Comprimento aproximado 4,75; comprimento da asa 3,51; largura da cabeça 1,56; comprimento da cabeça 1,25; comprimento do olho 0,89 . Tegumento predominantemente preto, castanho-enegrecido na cabeça com áreas castanhas no clípeo, supraclipeal e nas genas. Antenas com o escapo e o pedicelo castanhos, o flagelo castanho claro dorsalmente e amarelo-âmbar ventralmente a partir da ponta do terceiro flagelômero; tégulas e veias alares amarelo-âmbar, as tégulas translúcidas e as asas levemente tingidas de amarelo. Pernas amarelo-pálidas, com os artículos basais castanhos e a face externa dos fêmures e tíbias amarelo-acastanhadas; esporão mesotibial amarelo-esbranquiçado. Tergos e esternos pretos com a faixa marginal castanha passando a translúcida e amarelada na ponta.

Placa labral quase retangular, sem rúgulas, com a ponta um pouco arqueada e carenas laterais quase até a base; clípeo, supraclipeal e paroculares inferiores polidos, com pontos um pouco mais densos na supraclipeal e mais esparsos nas paroculares; supraclipeal quase plana, pouco elevada em direção à área interalveolar; sulco frontal curto, dos alvéolos até a metade da distância do alvéolo ao ocelo mediano, orlado por carenas fracas pontuadas; fóveas faciais em forma de gota muito estreita, mais larga na metade dorsal, longas como $1 / 3$ do comprimento do olho $(0,30: 0,89)$; paroculares inferiores deprimidas e um pouco elevadas medianamente. Mesoscuto e escutelo polidos e com pontos pouco menores que os clipeais, distribuídos irregularmente, deixando áreas sem pontos quase do tamanho do ocelo mediano; área basal do propódeo pouco mais longa que a metade do comprimento do metanoto, com rúgulas esparsas, um pouco mais longas no meio, o contorno posterior pouco marcado; esporão mesotibial com o dente apical alongado, 3 dentes muito curtos na metade apical e dentículos finos para a base; mesepisternos micro-reticulados com pontos finos esparsos. Tergo basal micro-reticulado e brilhante com pontos muito pequenos e esparsos nos lados, $2^{\circ}$ e $3^{\circ}$ tergos como o primeiro, a faixa marginal fracamente micro-reticulada e brilhante.

Pilosidade branca e curta na cabeça e mesoscuto; com aspecto aveludado no colar e nos lobos pronotais; esparsa e curta nos tergos, nos lados do $2^{\circ}$ ao $4^{\circ}$ com pêlos longos esparsos; os tergos e esternos distais com pêlos um pouco amarelados; face ventral dos mesepisternos com cerdas finas e longas, com a ponta ondulada ou arqueada. 
Holótipo fêmea. ARGENTINA, Entre Rios. "Prov. Entre Rios / Villaguay Arg. / XI - 20 - 1951 / Juan Foerster" (DZUP). Parátipos com os mesmos dados, 6 fêmeas; "Campana B. Aires / R. A. (F. N. G. B. M.) / XII - 1955 H. Walz", 1 fêmea (todos no DZUP).

Comentários. A fêmea de A. punctatus sp. nov. tem em comum com a fêmea de $A$. micans Urban, 1995, do Rio Grande do Sul, Brasil, o clípeo, área supraclipeal e parte da face polidos e com pontuação um pouco densa, porém A. micans difere pelo porte maior, cerca de 7,50 de comprimento, mesoscuto e escutelo polidos e denso-pontuados, área basal do propódeo curta e nitidamente delimitada e pelo tergo basal densopontuado. Um dos parátipos de Villaguay tem uma estria amarela no meio do clípeo e no parátipo de Buenos Aires falta o metassoma. Esta espécie é parcialmente simpátrica com $A$. villaguayensis $\mathbf{s p . ~ n o v . ~}$

Etimologia. Nome relativo ao aspecto da cabeça quase inteiramente polida e pontuada.

Macho desconhecido.

\section{Anthrenoides saltensis sp. nov.}

(Figs. 11, 14)

Diagnose. Fêmea com a cabeça um pouco mais larga que longa; fóveas faciais longas e largas, mais estreitas ventralmente; quase toda a placa labral com rúgulas divergentes da área médio-basal para os lados; mesoscuto e escutelo micro-reticulados; mesepisternos micro-reticulados com pontos finos e esparsos quase igualando o tamanho dos retículos; coxas anteriores com projeção apical achatada e larga, arredondada na ponta, sem cerdas na face medial porém com cerdas finas alongadas na face externa e em volta.

Holótipo fêmea. Comprimento aproximado 9,40; comprimento da asa 6,66; largura da cabeça 2,45; comprimento da cabeça 2,01; comprimento do olho 1,46. Tegumento predominantemente preto; exceto as antenas a partir do $4^{\circ}$ flagelômero castanho-escuras dorsalmente e de um cremeacinzentado na face ventral; face ventral do mesossoma e as pernas castanho-enegrecidas; tégulas enegrecidas, translúcidas; as asas tingidas de castanho-claro, veias castanhas exceto a $\mathrm{R}$ enegrecida. Pernas sem nódoa amarela na base das tíbias; esporão mesotibial enegrecido. Os dois tergos basais castanho-escuros com a faixa marginal castanha, tergos medianos e distais enegrecidos com a faixa marginal translúcida castanha pouco distinta, os esternos também enegrecidos com faixa marginal translúcida amarelada, muito estreita.

Placa labral trapezoidal e um pouco mais longa que sua largura apical, com rúgulas longas divergentes da área médiobasal para os lados e para a ponta deixando uma faixa apical lisa estreita, as carenas laterais longas porém não chegando à base; clípeo polido com pontos grandes e esparsos separados por espaços um pouco maiores que os pontos e uma linha mediana sem pontos; supraclipeal com pontos esparsos, brilhante e com micro-reticulação esparsa muito difusa; fronte com área elevada em carena baixa e larga entre os alvéolos, tendo uma pequena fóvea ventral unida a um sulco mediano muito delgado; fóveas faciais tão largas como um terço do seu comprimento e estreitando um pouco na ponta ventral, mais longas que $1 / 3$ do comprimento do olho (0,62: 155). Mesoscuto e escutelo micro-reticulados, com pontos finos separados por 2 a 5 diâmetros de ponto, mais esparsos no disco do mesoscuto e no escutelo; área basal do propódeo quase tão longa como o comprimento do metanoto, com rúgulas mais longas no meio e curtas porém um pouco divergentes nos flancos, o contorno posterior pouco marcado; mesepisternos micro-reticulados com pontos finos esparsos; coxas anteriores com projeção achatada e larga, arredondada na ponta, sem cerdas na face medial porém com cerdas finas alongadas na face externa e em volta; esporão mesotibial quase tão longo como o basitarso, com 6 dentes grossos, quase tão longos como a largura do esporão e pouco menores que o apical; tergos com microreticulação brilhante e pontos finos rasos pouco perceptíveis, a faixa marginal micro-reticulada e os pontos mais esparsos no tergo basal.

Pilosidade branca, curtíssima, denso-plumosa e com aspecto aveludado nos lobos pronotais e na parte posterior do colar pronotal; pêlos brancos nos artículos basais das pernas e de cor creme na face externa das tíbias anteriores e medianas, nas tíbias posteriores com cerdas inteiramente castanhas e cerdas castanhas com a ponta branca; mesepisternos com cerdas lisas, longas e semi-decumbentes na face ventral e pêlos curtos esparsos na face lateral; branca, muito esparsa e curta nos tergos, longa e fracamente amarelada nos dois apicais.

Holótipo fêmea. ARGENTINA, Salta. "RA: Salta / Pulares / 17 I - 73 J. L. Neff", "77976", "E” (DZUP). Parátipos: "S. P. Colalao Tucuman (R. A.) / II - 49 Arnau", 1 fêmea; "S. Pedro Colalao / Tucuman - R. Arg. / I - 1949 / P. J. M. Arnau leg.", 1 fêmea (todos no DZUP).

Comentário. As fêmeas de A. saltensis sp. nov. e de A. larocai Urban, 2005, têm em comum a projeção larga e achatada das coxas anteriores, com cerdas finas na face externa e em volta e pelo palpômero labial basal distintamente mais curto que a soma dos três distais. Anthrenoides larocai se distingue pela placa labral mais curta que a largura no ápice, densamente rugulosa na base e com rúgulas divergentes para os lados e para a ponta; pronoto com pilosidade alongada no colar e nos lobos, com mescla de pêlos muito curtos no colar porém sem aparência aveludada; escutelo polido ou com microreticulação fraca e brilhante; mesepisternos (fig. 13) com os pontos maiores que os retículos e pêlos alongados na face lateral; área basal do propódeo com rúgulas finas e irregulares.

Etimologia. Nome relativo à localidade-tipo.

Macho desconhecido.

\section{Anthrenoides sanpedroi sp. nov.} (Figs. 4, 12)

Diagnose. Tanto o macho como a fêmea com mesoscuto, escutelo e mesepisternos polidos; primeiro palpômero labial igualando a soma dos palpômeros distais. $\mathrm{O}$ macho com a placa labral preta e as máculas cefálicas esbranquiçadas; a 
fêmea com as fóveas faciais longas e largas e a face ventral dos mesepisternos sem cerdas de ponta dobrada em forma de gancho.

Holótipo macho. Comprimento aproximado 6,86; comprimento da asa 5,25; largura da cabeça 2,07; comprimento da cabeça 1,55; comprimento do olho 1,32. Tegumento predominante preto exceto o clípeo e as paroculares inferiores esbranquiçados, o clípeo com duas pequenas nódoas acastanhadas perto das fóveas tentoriais, as paroculares com a mácula até a metade da sutura subantenal externa, continuando em arco até as órbitas; antenas castanhoenegrecidas com a face ventral castanho-clara a partir do quarto flagelômero; tégulas translúcidas castanhas; asas tingidas de amarelo-acastanhado e as veias também desta cor; pernas castanhas, sem nódoa amarela na base das tíbias. De um castanho claro no tergo basal, em parte do segundo e do terceiro, a faixa marginal castanha, os demais tergos pretos; esternos com áreas castanhas e enegrecidas e faixa marginal translúcida, tingida levemente de castanho.

Placa labral quase retangular, com as margens laterais retas na metade basal e arredondadas para a ponta, as carenas laterais quase até a base; clípeo polido, sem carena mediana, com pontos distribuídos irregularmente, os intervalos variando de 1 a 4 diâmetros de ponto; supraclipeal polida, não protuberante, elevada em direção à área interalveolar, com pontos esparsos no disco e mais densos nos flancos; carena frontal fina e curta, entre os alvéolos; fóveas faciais largas e tão longas como 1/4 do comprimento do olho $(0,34: 1,32)$; genas arredondadas, sem angulosidade ventral; mesoscuto e escutelo polidos com pontos esparsos; mesepisternos polidos nos lados, com pontos como os do mesoscuto porém mais esparsos; área basal do propódeo com rúgulas paralelas no meio e divergentes dos lados, o contorno posterior bem marcado. Tergos polidos com larga margem lisa brilhante, o basal com pontos finos esparsos, os demais com pontuação um pouco densa. Sexto esterno com o recorte mediano em "U" mais longo que largo, com a metade basal um pouco mais larga que a distal e as margens laterais contínuas com a carena basal em arco; ponta do oitavo esterno arredondada e tão larga como o diâmetro do ocelo mediano.

Pilosidade esbranquiçada e curta, com mescla de pêlos longos na parte posterior do colar pronotal e nos lobos; esparsa e curta nos tergos.

Fêmea. Comprimento aproximado 8,62; comprimento da asa 6,96; largura da cabeça 2,32; comprimento da cabeça 1,92 ; comprimento do olho 1,51. Tegumento preto predominando, as antenas como no macho; tégulas translúcidas castanhas; as asas como no macho; pernas com áreas enegrecidas e castanhas, sem área basal amarela nas tíbias, os tarsômeros castanhos; esporão mesotibial preto nos $2 / 3$ basais, acastanhado subapicalmente e com a ponta amareloacastanhada.

Placa labral trapezoidal, tão longa como a sua largura apical e com os cantos arredondados, as carenas laterais quase até a base, com uma rúgula mediana muito fina nos $2 / 3$ dorsais e rúgulas látero-basais divergentes; clípeo e supraclipeal polidos, com a pontuação um pouco densa, os pontos iguais aos intervalos ou pouco maiores no clípeo; carena mediana baixa no clípeo; carena frontal fina, ultrapassando a tangente alveolar dorsal; fóveas faciais alongadas, um pouco estreitadas inferiormente, largas e mais longas que $1 / 3$ do comprimento do olho $(0,62: 1,51)$; mesoscuto e escutelo polidos com pontos esparsos, os intervalos entre os pontos maiores no escutelo; base do propódeo mais curta que o metanoto, com poucas rúgulas, o contorno posterior evidente; mesepisternos polidos nos lados, com pontos esparsos e áreas micro-reticuladas; esporão mesotibial quase tão longo como o basitarso, com 9 dentes curtos e delgados e dentículos para a base; tergos micro-reticulados e brilhantes, com faixa marginal micro-reticulada e pontuação densa, exceto o basal com pontos muito finos esparsos.

Pilosidade predominantemente branca, no pronoto como no macho; castanha nas tíbias e basitarsos, castanhoamarelada nos tarsômeros intermediários e distais, cremeacastanhada na face ventral dos basitarsos anteriores e medianos e creme na face ventral dos basitarsos posteriores; face externa das tíbias posteriores com cerdas castanhas e algumas bicoloridas, esbranquiçadas na ponta e com a base castanha; área ventral dos mesepisternos com cerdas finas semi-decumbentes, com a ponta reta ou levemente arqueada.

Holótipo macho. ARGENTINA, Tucumán. "San Pedro / de Colalao / Dto. Trancas / Tucuman / Arg. II - 1951”, sem indicação de coletor, (DZUP). Parátipos: "S. de La Ventana / Prov. B. Aires / 2 - III - 1954 / M. A. Fritz leg", 2 fêmeas; "S. P. Colalao / Tucuman (R. A.) / I - 49 Arnau", 1 fêmea (todos no DZUP).

Comentário. Em um dos parátipos de Sierra de la Ventana, as asas anteriores com a segunda célula submarginal parcialmente aberta e no parátipo de Tucumán a carena mediana do clípeo pouco perceptível. Na chave de Urban (2005a), o macho sai com A. pinhalensis Urban, 2005 que difere pelo mesoscuto, escutelo e os mesepisternos micro-reticulados, brilhantes; pela angulosidade ventral nas genas e pelo palpômero basal do lábio, medindo até o dobro da soma dos palpômeros distais. A fêmea sai com A. antonii Urban, 2005, pelo tegumento em grande parte polido, porém esta difere por ter a área basal do propódeo micro-reticulada e desprovida de rúgulas, a cabeça distintamente mais larga que longa $(2,53$ : 1,83 ) e os esporões mesotibiais castanho-pálidos, com três dentes subapicais mais longos que os restantes.

Etimologia. Nome relativo à localidade-tipo.

\section{Anthrenoides tucumanus sp. nov.}

(Figs. 5, 18)

Diagnose. Macho com as máculas cefálicas amarelas, a cabeça em grande parte fosca, o clípeo polido com áreas microreticuladas esparsas; as genas largas com a angulosidade ventral projetada para trás em forma de tubérculo arredondado; gáleas curtas, aproximadamente a metade do comprimento do 
olho; os tergos apicais de cor âmbar e os basais parcialmente enegrecidos.

Holótipo macho. Comprimento aproximado 7,48; comprimento da asa 5,19; largura da cabeça 2,26; comprimento da cabeça 1,71; comprimento do olho 1,21. Tegumento preto menos o clípeo e as paroculares inferiores amarelos, o clípeo com a margem e duas nódoas pretas arredondadas próximas das fóveas tentoriais, as máculas paroculares quadráticas, até a metade da sutura subantenal externa, o contorno dorsal sinuado; antenas pretas no lado dorsal e castanhoenegrecidas ventralmente do segundo flagelômero ao subapical, o último artículo preto; tégulas translúcidas enegrecidas, asas tingidas de castanho-amarelado com as veias castanhas; pernas castanhas com áreas enegrecidas, sem nódoa basal amarela nas tíbias; três tergos basais castanhos com faixa marginal translúcida amarelo-âmbar, o quarto tergo castanho só no disco com larga faixa marginal de cor âmbar, os tergos distais quase inteiramente âmbar; esternos com áreas castanhas e enegrecidas, a faixa marginal translúcida amarelopalha; os lados do quarto e quinto esternos amarelo-âmbar e o sexto inteiramente dessa cor.

Placa labral retangular com as carenas laterais na metade distal; clípeo polido, com micro-reticulação muito superficial em pequenas áreas, sem carena mediana e com pontos separados por espaços variáveis, alguns maiores que o diâmetro do ocelo mediano; supraclipeal micro-reticulada e fosca, sem pontos, achatada junto ao clípeo e com uma pequena projeção mediana ao nível da tangente inferior dos alvéolos; carena frontal fina e irregular, ultrapassando a tangente dorsal dos alvéolos; parte das paroculares inferiores e toda a área dorsal da cabeça até o vértice foscos devido à micro-reticulação densa, com pontos rasos esparsos; fóveas faciais medindo cerca de $1 / 4$ do comprimento do olho $(0,31$ : $1,21)$; genas largas e com angulosidade ventral projetada em tubérculo arredondado, mais largas que os olhos em vista de perfil; mesoscuto micro-reticulado, um pouco brilhante, com pontos rasos e esparsos; escutelo micro-reticulado com os pontos mais esparsos que os do mesoscuto; área basal do propódeo mais longa que o metanoto, com rúgulas finas irregulares e o contorno posterior marcado somente no meio; mesepisternos micro-reticulados com pontos esparsos muito finos; tergos micro-reticulados e brilhantes com a faixa marginal brilhante e fracamente micro-reticulada; o tergo basal com pontos finíssimos muito esparsos, no segundo os pontos um pouco densos e nos demais tergos os pontos esparsos; sexto esterno com o recorte em "U" quase tão largo como longo, com as margens laterais paralelas no terço basal e, a seguir divergindo para os lados, basalmente as margens do recorte continuando em forma de carenas laterais arqueadas, separadas por um espaço igual ao diâmetro do ocelo mediano; ponta da projeção mediana do oitavo esterno um pouco mais estreita que o diâmetro do ocelo mediano, com os cantos arredondados e uma fraca emarginação.

Pilosidade branca, alongada na face posterior do colar e nos lobos pronotais; esparsa e longa no mesoscuto, intercalada com pêlos curtos; amarelada na face ventral dos basitarsos; muito curta nos tergos basais, o sexto tergo com franja subapical rala e decumbente, o distal com pilosidade longa de cor creme.

Holótipo macho. ARGENTINA, Tucumán. "ARGENTINA, Pr. Tucumán / Las Lenguas / collector J. L. Neff / 5 - XII - 73", "86903" (DZUP).

Comentários. Na chave de Urban (2005a) sai com A. paolae Urban, 2005, do sul do Brasil, que tem a face fosca, incluindo o clípeo e as paroculares inferiores, os tergos enegrecidos com faixa marginal translúcida castanha e as genas angulosas ventralmente.

Etimologia. Nome relativo à localidade-tipo.

Fêmea desconhecida.

\section{Anthrenoides villaguayensis sp. nov.} (Fig. 6)

Diagnose. Macho com as fóveas tentoriais na sutura epistomal, próximas da coalescência com as suturas subantenais externas; áreas subantenais muito estreitadas ventralmente e em parte esbranquiçadas, demais máculas cefálicas esbranquiçadas e o sexto esterno com o recorte em "U" mais largo que longo.

Holótipo macho. Comprimento aproximado 6,08; comprimento da asa 4,23; largura da cabeça 2,10; comprimento da cabeça 1,73; comprimento do olho 1,24. Tegumento preto, menos o labro, clípeo, paroculares inferiores e os $2 / 3$ inferiores das áreas subantenais esbranquiçados, o clípeo com duas nódoas arredondadas castanhas próximas das fóveas tentoriais; as máculas paroculares grandes e quase quadrangulares, ultrapassando a metade das suturas subantenais externas e mais longas junto aos olhos; antenas com o escapo e o pedicelo castanho-enegrecidos e brilhantes, os demais artículos foscos com a face dorsal castanha e a ventral castanho-amarelada; tégulas amarelo-acastanhadas; as asas tingidas de amarelado, pterostigma e veias amareloâmbar; as pernas castanhas com nódoa amarela na base das tíbias, nas posteriores a nódoa ocupando toda a placa basitibial. Tergos basais castanho-amarelados e os demais castanho-avermelhados, com larga margem translúcida fracamente acastanhada.

Placa labral curta e retangular, com as carenas laterais um pouco divergentes dorsalmente; clípeo polido e sem carena mediana, com pontos pequenos esparsos; as fóveas tentoriais nos ramos laterais da sutura epistomal, separadas das suturas subantenais externas por aproximadamente meio diâmetro de ocelo; supraclipeal não protuberante, um pouco elevada dorsalmente, polida e com micro-reticulação fraquíssima em pequenas áreas, sem pontos no disco, porém com pontuação densa junto às suturas subantenais; áreas subantenais muito estreitas ventralmente, as suturas paralelas só no terço dorsal; carena frontal curta e muito fina até metade da distância dos alvéolos ao ocelo mediano; fóveas faciais rasas, ovaladas e 
tão longas como $1 / 5$ do comprimento do olho $(0,24: 1,24)$; paroculares inferiores polidas e um pouco infladas, não deprimidas, com pontos como os do clípeo; paroculares superiores pontuadas, com os intervalos entre os pontos medindo um a dois diâmetros de ponto, com micro-reticulação fraca e brilhante; genas com o contorno posterior arredondado. Mesoscuto polido e com pontuação esparsa, os pontos pequenos separados por intervalos variando de 3 diâmetros de ponto até o tamanho do ocelo; escutelo polido e com a pontuação mais esparsa que a do mesoscuto; área basal do propódeo em forma de meia-lua, com rugosidades anastomosadas e sem contorno posterior distinto; mesepisternos micro-reticulados, foscos, com pontos esparsos; tergos micro-reticulados brilhantes, com faixa marginal translúcida brilhante e micro-reticulada, o basal com os pontos um pouco densos no disco; sexto esterno com o recorte mediano em "U" largo porém curto, a largura igual ao dobro do comprimento, com as margens laterais prolongadas basalmente em carenas muito curtas; ponta da projeção mediana do oitavo esterno larga como o dobro do diâmetro do ocelo mediano.

Pilosidade branca, pouco conspícua na cabeça; curta e com mescla de pêlos alongados na parte posterior do colar pronotal, nos lobos pronotais e no mesoscuto, os pêlos mais esparsos no mesoscuto; tergos com pêlos eretos e esparsos na base e no disco, misturados com pêlos curtos decumbentes também esparsos; do quarto ao sexto tergo com franja esparsa, decumbente e longa.

Holótipo macho. ARGENTINA, Entre Rios. "Prov. Entre Rios / Villaguay Arg. / XI -20 - 1951, Juan Foerster” (DZUP).

Comentário. As demais espécies de Anthrenoides diferem de A. villaguayensis $\mathbf{S p}$. nov. pelas fóveas tentoriais, localizadas no ponto de união das suturas subantenais externas com a sutura epistomal e, pelas áreas subantenais largas, estreitando somente junto à sutura epistomal.

Etimologia. Nome relativo à localidade-tipo.

Fêmea desconhecida.

Chave para a identificação das espécies da Argentina Machos

1. Áreas subantenais em grande parte esbranquiçadas; fóveas tentoriais na sutura epistomal, afastadas das suturas subantenais externas .....

A. villaguayensis $\mathbf{s p . ~ n o v . ~}$

Áreas subantenais inteiramente pretas; fóveas tentoriais na união das suturas epistomal e subantenal externa

2. Máculas cefálicas esbranquiçadas .................................... 3

Máculas cefálicas amarelas .............................................. 4

3. Mesepisternos polidos e pontuados, sem microreticulação e com pontos grandes, como os mesoscutais; supraclipeal polida com pontuação um pouco densa

A. sanpedroi $\mathbf{s p . ~ n o v . ~}$

Mesepisternos micro-reticulados com pontos muito finos e rasos; supraclipeal micro-reticulada e quase fosca, com pontos rasos esparsos ..... A. calderensis sp. nov.

4. Tergo basal polido 5

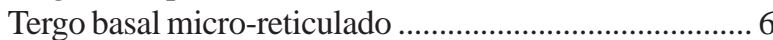

5. Supraclipeal um pouco achatada, no mesmo plano do clípeo; tergos denso-pontuados com os intervalos menores que os pontos, a faixa marginal fosca e lineolada. A. neffi sp. nov.

Supraclipeal protuberante; tergos com pontuação esparsa, os intervalos entre os pontos maiores que 2 diâmetros de ponto, faixa marginal lisa e brilhante .... A. meridionalis

6. Tegumento castanho nos tergos, menos os distais enegrecidos; mesoscuto e escutelo polidos

A. cordobensis sp. nov.

Tegumento amarelo-âmbar nos tergos, com áreas pretas nos basais; mesoscuto e escutelo micro-reticulados e brilhantes A. tucumanus sp. nov.

Fêmeas

1. Cabeça com projeções dorsais em forma de gibas, duas menores junto à área ocelar e duas alongadas em meialua junto aos olhos; fóveas faciais na altura dos ocelos laterais, nos lados do vértice .

A. gibberosus sp. nov.

Cabeça sem projeções dorsais em forma de gibas; fóveas faciais ventralmente aos ocelos, nas paroculares superiores

2. Coxas anteriores com projeção apical achatada e larga, arredondada, sem cerdas na face medial porém com cerdas finas alongadas na face externa e em volta; placa labral quase inteiramente ornada com rúgulas divergentes da área médio-basal para os lados

..A. saltensis $\mathbf{s p . ~ n o v . ~}$

Coxas anteriores sem projeção apical em forma de lâmina; placa labral sem rúgulas ou com rúgulas esparsas na metade basal

3. Basitarsos anteriores arqueados dorso-ventralmente, ornados na ponta com algumas cerdas finas e longas em forma de gancho, estas cerdas também nos tarsômeros intermediários; mesoscuto densopontuado A. neffi sp. nov.

Basitarsos anteriores retos, não arqueados dorsoventralmente, sem cerdas modificadas, os tarsômeros intermediários sem cerdas modificadas; mesoscuto com pontuação variável

4. Mesepisternos com áreas polidas na face lateral e as cerdas da face ventral semi-decumbentes, retas ou 
levemente arqueadas; com carena frontal

A. sanpedroi sp. nov.

Mesepisternos sem áreas laterais polidas e com a face ventral revestida com cerdas eretas dobradas na ponta em forma de gancho; fronte com o tegumento elevado medianamente e com um sulco mediano fino ou com carena frontal

5

5. Supraclipeal micro-reticulada; com carena frontal fina; esporão mesotibial enegrecido com 6 dentes fortes ... A. calderensis $\mathbf{s p . ~ n o v . ~}$

Supraclipeal polida; fronte sem carena mediana, com sulco fino orlado por elevações do tegumento; esporão mesotibial amarelo-âmbar com 3 ou 4 dentes fortes ou todos curtos

6. Supraclipeal com pontuação no disco e nos flancos; sulco frontal irregular, orlado por tegumento elevado e denso pontuado; esporões mesotibiais com dentes muito curtos

A. punctatus sp. nov.

Supraclipeal sem pontos no disco, com pontos somente junto às suturas subantenais; sulco frontal fino e liso; esporões mesotibiais com 3 a 4 dentes fortes 7

7. Tergo basal micro-reticulado com pouquíssimos pontos e pequena área polida subapical nos cantos; supraclipeal elevada para o meio em direção ao sulco frontal; tergos com faixa marginal translúcida amarelada A. cordobensis sp. nov.

Tergo basal polido com pontos finos um pouco densos, separados espaços de 2 a 4 diâmetros de ponto, com micro-reticulação brilhante em áreas esparsas; supraclipeal protuberante, gibosa, não elevada para o meio em direção ao sulco frontal; tergos com faixa marginal translúcida castanha A. meridionalis

Na chave constam somente os machos de A. villaguayensis sp. nov. e de $A$. tucumanus sp. nov., somente as fêmeas de $A$. gibberosus sp. nov., A. saltensis sp. nov. e A. punctatus $\mathbf{s p . ~ n o v . ~}$ Não foi examinado nenhum Anthrenoides meridionalis coletado na Argentina, somente espécimes coletados no Brasil.

Agradecimentos. A Aline Cristina Martins e M. Sc. Lisiane Dilli Wendt (Projeto Taxon line - Rede Paranaense de Coleções Biológicas) pelas fotos que ilustram o trabalho, e à M. Sc. Kelli dos Santos Ramos pela elaboração das pranchas.

\section{REFERÊNCIAS}

Moure, J. S.; D. Urban \& A. DalMolin, 2007. Protandrenini Robertson, 1904: 24-27. In: Moure, J. S.; D. Urban \& G. A. R. Melo. Catalogue of Bees (Hymenoptera, Apoidea) in the Neotropical Region. Curitiba, Sociedade Brasileira de Entomologia $\mathrm{XIV}+1058 \mathrm{p}$.

Urban, D. 2005a. Espécies novas de Anthrenoides Ducke (Hymenoptera, Andrenidae) do Brasil. Revista Brasileira de Entomologia 49: 36-62.

Urban, D. 2005b. Espécies novas de Anthrenoides Ducke (Hymenoptera, Andrenidae) do nordeste do Brasil. Acta Biológica Paranaense 34: 73-87.

Urban, D. 2007. Espécies novas de Anthrenoides Ducke (Hymenoptera, Andreninae) do Sudeste do Brasil. Revista Brasileira de Entomologia 51: 23-34. 